\title{
Determinants of Support for Climate Change Efforts in the Global South
}

\author{
By Emmanuel Adugu, Ph.D.
}

\begin{abstract}
This paper addresses determinants that underpin support for climate change efforts. The study is based on Pew Research Center (USA), Spring 2015 Global Attitudes survey dataset, with a primary focus on climate change, collected from March 25 to May 27, 2015. Drawing on the new ecological paradigm and ecological modernization perspectives, the paper utilizing logistic regression, examines the relationship between individuals' perception or awareness of the severity of climate change and their support for limiting greenhouse emissions; the extent to which individuals' views on whether developing countries should do as much as the rich countries in addressing climate change predict the likelihood of their (individuals') support for limiting greenhouse emissions. The logistic regression models reveal that people's rational insight into the following consequences of climate change positively predicts support for limiting greenhouse emissions: severe weather like floods or severe storms; long periods of unusually hot weather; rising sea levels; years of schooling and age positively predict support for limiting greenhouse emissions. In general, knowing an individual's country of residence offers no predictive value in determining whether the individual will support limiting greenhouse emissions. The notable exceptions are: South Africa, Nigeria, Ghana and Kenya. These four countries display positive and statistically significant coefficients in the logistic regression model predicting support for greenhouse emissions.
\end{abstract}

Keywords: climate change; environmental concern; greenhouse emissions; ecological crisis; Africa

\section{Introduction}

Across the globe, many publics irrespective of gender, age or class are convinced that climate change has an anthropogenic cause. Currently, climate change is the most profound environmental problem facing human society. In that context, there is a growing perceived threat to livelihood systems from climate change, especially in developing countries. It is notable, based on survey research that in Africa, climate change is seen as top concern compared with global economic instability, cyber-attacks on governments, banks or corporations (PEW, 2015). The high concern about climate change in Africa may be linked to the perception of its severity.

The Intergovernmental Panel on Climate Change (IPCC) characterized climate change as "any change in climate over time, whether due to natural variability or as a result of human activity" (IPCC, 2007, p.30). The implication of this characterization is that climate change could be conceived in terms of global warming or global cooling. However, the term is usually concerned with global warming. Human activities are estimated to have caused approximately $1.0^{\circ} \mathrm{C}$ of global warming above pre-industrial levels (IPCC, 2018, p.4). Global warming is the estimated increase in global mean surface 
temperature averaged over a 30-year period centered on a particular year or decade, expressed relative to pre-industrial levels unless otherwise specified (IPCC, 2018, p. 24.). It is widely accepted in the scientific community that the major causes of global warming are rising concentrations of greenhouse gases (GHGs) - notably, carbon dioxide $\left(\mathrm{CO}_{2}\right)$, methane $\left(\mathrm{CH}_{4}\right)$, and nitrogen dioxide $\left(\mathrm{NO}_{2}\right)$, in the earth's atmosphere. GHGs trap heat to the earth's surface-though there is a differential heat trap ability of GHSs, their cumulative effect can substantially and effectively disrupt the conditions suitable for all natural species. Currently, the atmospheric concentrations of GHGs gases greatly exceeds pre-industrial levels (IPCC, 2014). This development has serious implications for ecological crises such as drought or water shortages, severe weather like floods or storms, long periods of unusually hot weather and rising sea levels.

This study addresses determinants that underpin support for climate change efforts in Africa. Drawing on the new ecological paradigm and ecological modernization perspectives, the paper examines the relationship between individuals' perception or awareness of the severity of climate change and their support for limiting greenhouse emissions; the extent to which individuals' views on whether developing countries should do as much as the rich countries in addressing climate change predict the likelihood of their (individuals') support for limiting greenhouse emissions. The merits of the new ecological paradigm and ecological modernization perspectives will be assessed empirically in the context of the data.

\section{Theoretical Perspectives}

Environmental concern is not "the preserve" of only those in the global North. The publics in both developed and developing countries are concerned about their environment well-being. Even though developing nations have fewer post-materialists (compared with their developed counterparts), published and credible research reveals that in some instances, developing countries are relatively more concerned about environmental conditions in their local communities compared with those in developed nations (Brechin \& Kempton 1994). Prominent environmental scholars support this view. In that context, Dunlap \& Mertig (1997) noted that even though developing countries hold materialist views, they have values of environmental concern and reveal attitudes of more concern for their environment than those in post-materialist societies. These facts are apparently anomalies for the post-materialist perspective which anticipates that citizens of developed countries should rather be more environmentallyconcerned in relation to the developing ones. This apparent anomaly might be explained by the ecological paradigm.

Humans are increasing understanding the linkage between their activities and the environment - the benefits and costs of their activities for current and future generations, irrespective of their geographical location and economic circumstances. A study by Diez, Dan \& Shwom (2007) shows that willingness to support policies for the reduction of emission of greenhouse is high among respondents. Diez and colleagues further noted that their research revealed people's recognition of the need to take action in mitigating the effects of climate change in view of its potential negative impact on 
their living standards. Apparently, the acceptance of pro-ecological attitudes may result in the rejection of human exceptionalism (Dunlap and Catton, 1994). Obviously, the ecological paradigm and post-materialist perspectives provide insight into rational behaviors of citizens in both the Global North and South.

Another school of thought on the relationship between the physical environment and human activities is the ecological modernization perspective. Mol (2002, p.93) noted that the ecological modernization perspective posits that the economy and environment can decouple from one another through a transformation of ideas and processes that incorporate ecological considerations into the economy in addition to social institutions. The central argument of the ecological modernization perspective is that principal institutions in today's societies can be organized differently in order to be able to efficiently and effectively respond to challenges of the ecosystem (Murphy and Gouldson, 2009; Buttel, 2009). In a similar vein, ecological modernization relates to restructuring production and consumption processes in today's societies to deal with the consequent ecological crisis (Spaargaren and Mol, 2009). In that context, technological innovations may facilitate an environmentally-friendly production and consumption (Huber, 2009; Mol and Jannicke, 2009; Jenson and Gram-Hanssen, 2008).

\section{Data and Measurement of Variables}

This article is based on Pew Research Center's Spring 2015 Global Attitudes survey dataset with a primary focus on climate change, collected from March 25 to May 27, 2015. Pew Research Center is a non-partisan "fact tank" located in Washington, DC, USA. It provides information on global attitudes, US policy, science and technology, public opinion and demographic trends. The nationally representative dataset used for this paper, covered the following African countries: South Africa, Nigeria, Ghana, Senegal, Uganda, Kenya, Ethiopia, Tanzania, and Burkina Faso. The total sample size is 9062. It is worthy of note that the final dataset used for this paper was weighted to ensure proportional representation of each country (stratum).

\subsection{Variable Construction and Relevant Descriptive Statistics}

The dependent variable used is "whether a person supports or opposes limiting greenhouse emissions such as from burning coal or [gas/petrol]. The explanatory variables are: a series of four questions used to construct a scale of perception of severity of global climate change, awareness of specific environmental problems, responsibility in addressing climate change, effects of global climate change, perception of foreign companies in oil, petrol or mining in terms of (contributing to economic growth, providing local jobs, and not paying taxes), political participation, years of schooling, age, gender and country level dummies. Tables 1 and 2 report descriptive statistics of dependent and independent variables.

\subsection{Dependent variable}

Support or opposition to limiting greenhouse emissions as part of an international agreement was used as the dependent variable. Specifically, respondents 
were asked the following question: "countries from around the world will meet in December in Paris to deal with global climate change. They will discuss an agreement to limit greenhouse gas emissions, such as from burning coal or [gas/petrol]. Do you support or oppose limiting its greenhouse gas emissions as part of such an agreement?" Support for the agreement was coded 1 and opposition to it was coded 2. On average, an overwhelming number of respondents (i.e.74.4\%) of respondents in all nine (9) countries supported limiting greenhouse emissions. These responses were recoded into support $=1$, and oppose $=0$, necessary for data reduction and multivariate analytical purposes. The results are shown in Table 1 below. There is a broad public support for limiting greenhouse emissions, with Uganda having the highest level $(81.5 \%)$ of support among its publics. The data is depicted in Figure 1.

Table 1: Support or opposition to limiting greenhouse emissions as part of Paris agreement

\begin{tabular}{|c|c|c|c|c|c|c|c|c|c|c|}
\hline \multirow[b]{2}{*}{$\begin{array}{l}\text { Limiting } \\
\text { greenhouse } \\
\text { emissions as } \\
\text { part of Paris } \\
\text { agreement }\end{array}$} & \multicolumn{10}{|c|}{ Country } \\
\hline & 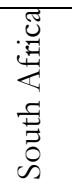 & 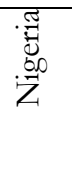 & 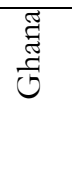 & 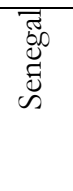 & 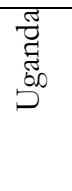 & 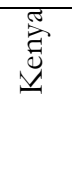 & 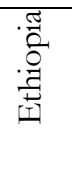 & 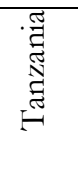 & 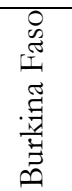 & 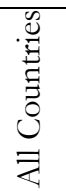 \\
\hline Support $(\%)$ & 62.4 & 70.5 & 76.5 & 78.6 & 81.5 & 69.1 & 77.4 & 74.2 & 77.5 & 74.4 \\
\hline Oppose (\%) & 37.6 & 29.5 & 23.5 & 21.4 & 18.5 & 30.9 & 22.6 & 25.8 & 22.5 & 25.6 \\
\hline
\end{tabular}

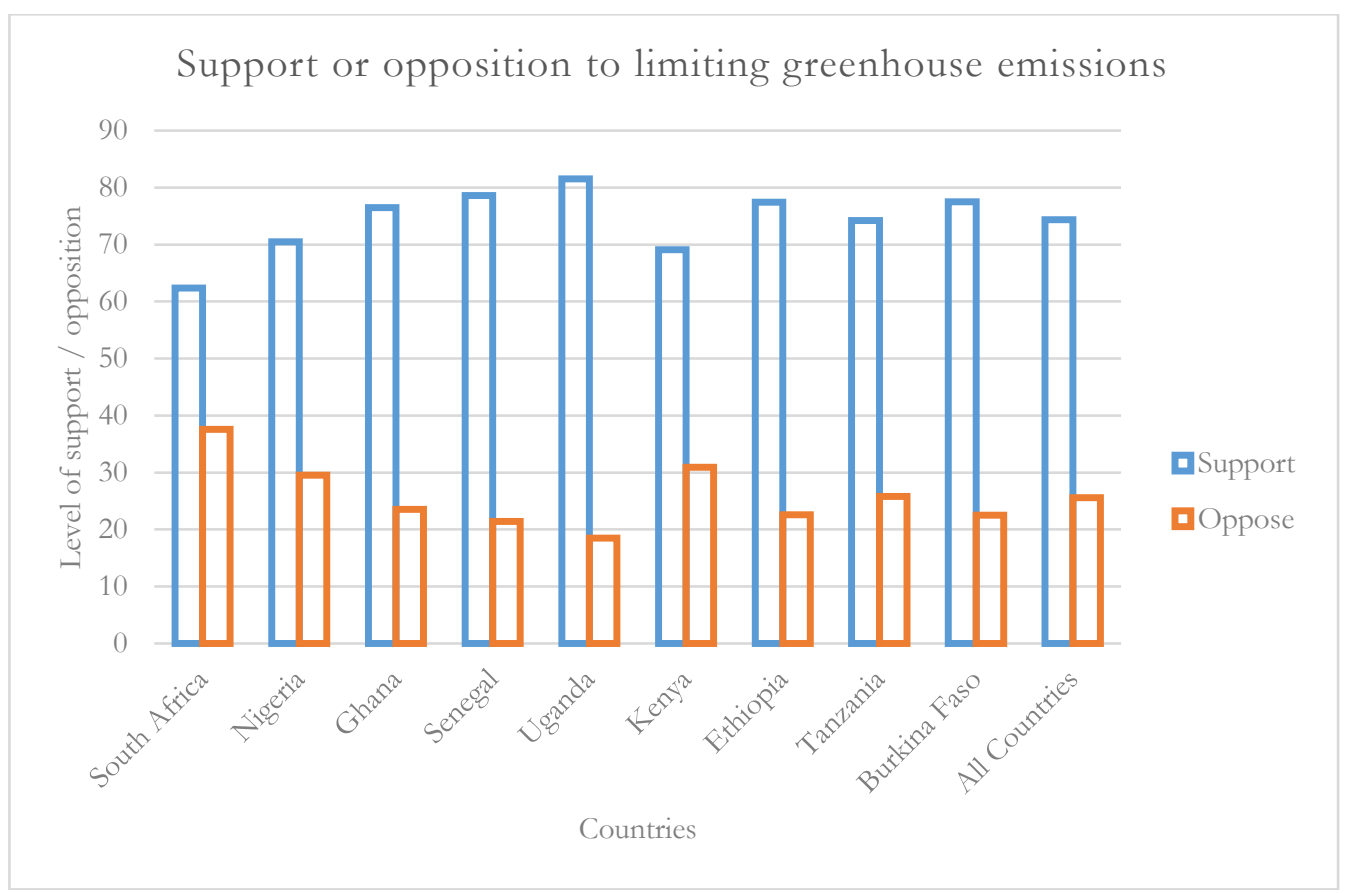

Figure 1: Support or opposition to limiting greenhouse emissions 


\subsection{Independent variables}

The socio-demographic variables examined are: age, years of schooling and gender. Age is measured in years. The average age for the nine countries was 35.9 years. On average, $50.2 \%$ of the sample were female and $49.8 \%$ were male. With respect to years of schooling, South Africa had the highest value of 10.9 compared with Burkina Faso, which has the lowest years of schooling (with a value of 3.9). The average years of schooling for the sample was 7.7.

Environmental concern is normally conceptualized with at least two of the following components: cognitive, conative and affective. In that context, it refers to "the degree to which people are aware of problems regarding the environment and support efforts to solve them" (Dunlap and Jones, 2002, p. 485). Frazen and Mayer (2010), define environmental concern as an individual's insight into how individuals endanger the natural environment coupled with the willingness to protect it. The above two definitions embody the cognitive and conative components. Typically, the concept of environmental concern is operationalized in relation to awareness or perceptions of the severity of specific problems and positive attitudes towards environmental protection (Marquart-Pyatt 2012). In this paper, the concept is operationalized as: having awareness or perception of the severity of specific environmental problems that endanger the natural environment coupled with a willing attitude to take action to protect it for current and future generations.

A scale of perception of the severity of global climate change was constructed using the following four items: the first item asked respondents how concerned they are about global climate change as an international issue. The response options were: very concerned (coded 1), somewhat concerned (coded 2), not too concerned (coded 3) and not at all concerned (coded 4). These were reverse coded so that higher values were associated with greater levels of concern. The second item asked respondents to indicate the seriousness of global climate change. The response options were: very serious (coded 1), somewhat serious (coded 2), not too serious (coded 3), not a problem (coded 4). These were also reverse coded so that higher values are associate with greater levels of seriousness. The third item on the scale of perception of the severity of global climate change asked respondents "Do you think global climate change is harming people around the world now, will harm people in the next few years, will not harm people for many years or will never harm people"? The response options were: now (coded 1), in the next few years (coded 2), not for many years (coded 3), and never (coded 4). Similar to the previous items, the response options were reverse coded so that higher values reflect higher levels of urgency. The final item asked respondents to indicate how concerned they are that global climate change will harm them personally at some point in their lifetime. The response options were: very concerned (coded 1), somewhat concerned (coded 2), not too concerned (coded 3) and not at all concerned (coded 4). These were reverse coded so that higher values were associated with greater levels of concern. An explorative factor analysis with varimax rotation indicates the four items fall into one dimension, with strong loadings. The Cronbach's alpha coefficient of an additive scale of perception of the severity of global climate change of the four items is .71. This indicates high reliability of the scale. The results are shown in Table 2 below. 
Turning to specific environmental problems, respondents were asked to indicate their views with respect to pollution and other forms of environmental damage; and lack of clean drinking water. The response options were: very big problem (coded 1), moderately big problem (coded 2), small problem (coded 3) and not a problem at all (coded 4). These were subsequently reverse coded so that greater values reflect higher levels of nature of the environmental problem. As shown in Table 2, in general, there is a high awareness among respondents that they lack clean drinking water, with Burkina Faso recording the highest value. This is not surprising due to the fact that Burkina Faso is drought-prone and among the poorest countries in the world. The country is known to have dilapidated water supply facilities coupled with lack of access to basic sanitation.

Table 2: Mean of variables in environmental concern scale

\begin{tabular}{|c|c|c|c|c|c|c|c|c|c|c|}
\hline \multirow[t]{2}{*}{$\begin{array}{l}\text { Variable } \\
\end{array}$} & \multicolumn{10}{|c|}{ Country Mean } \\
\hline & 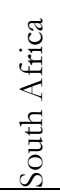 & 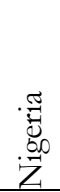 & 胥 & 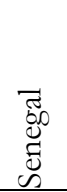 & 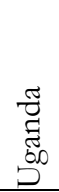 & 莺 & 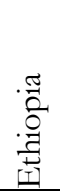 & 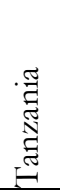 & 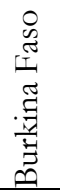 & 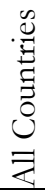 \\
\hline \multicolumn{11}{|c|}{ Perception of severity of global climate change } \\
\hline $\begin{array}{l}\text { Global climate change } \\
\text { is an international } \\
\text { concern }\end{array}$ & 3.2 & 3.6 & 3.6 & 3.2 & 3.6 & 3.4 & 3.4 & 3.2 & 3.7 & 3.5 \\
\hline $\begin{array}{l}\text { Global climate change } \\
\text { is serious }\end{array}$ & 3.2 & 3.5 & 3.6 & 3.4 & 3.6 & 3.5 & 3.1 & 3.4 & 3.7 & 3.5 \\
\hline $\begin{array}{l}\text { Global climate change } \\
\text { is harming people }\end{array}$ & 3.1 & 3.4 & 3.5 & 3.3 & 3.7 & 3.4 & 3.0 & 3.4 & 3.8 & 3.4 \\
\hline $\begin{array}{l}\text { Global climate change } \\
\text { will harm you } \\
\text { personally }\end{array}$ & 3.1 & 3.6 & 3.7 & 3.3 & 3.8 & 3.5 & 3.4 & 3.4 & 3.7 & 3.5 \\
\hline \multicolumn{11}{|c|}{ Cronbach's alpha $=0.71$} \\
\hline \multicolumn{11}{|c|}{ Awareness of specific problem in country } \\
\hline $\begin{array}{l}\text { Problem of pollution } \\
\text { and other forms of } \\
\text { environmental } \\
\text { damage }\end{array}$ & 3.4 & 3.5 & 3.5 & 3.5 & 3.1 & 3.0 & 3.0 & 3.4 & 3.3 & 3.3 \\
\hline $\begin{array}{l}\text { Problem of lack of } \\
\text { clean drinking water }\end{array}$ & 3.2 & 3.6 & 3.7 & 3.8 & 3.6 & 3.2 & 3.4 & 3.7 & 3.9 & 3.6 \\
\hline
\end{tabular}

$\mathrm{N}=8743$ 


\section{Perception and awareness of global climate change}

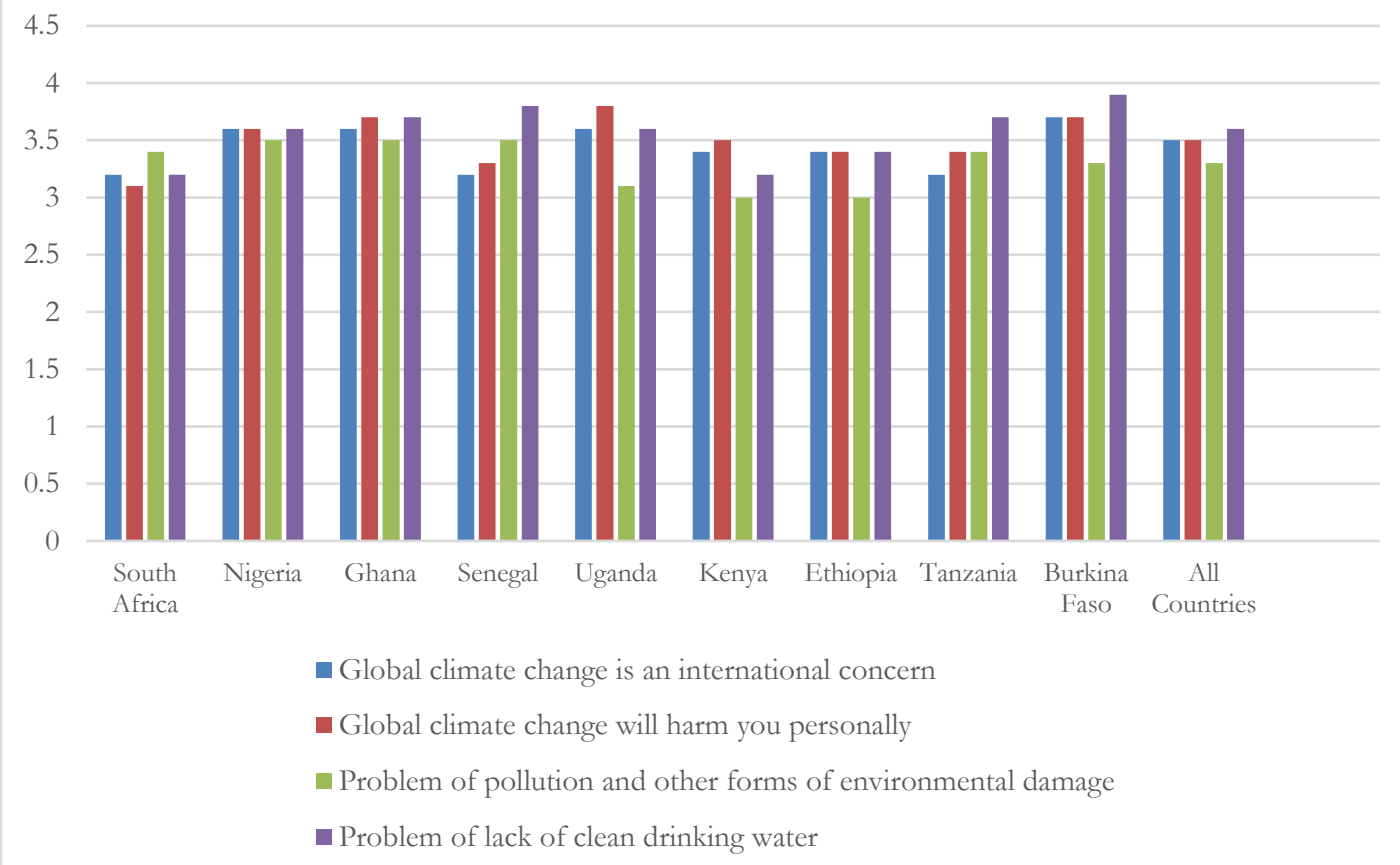

Figure 2: Perception and awareness of global climate change

Respondents' views were sought on addressing the problem of global climate change. In that regard, they were asked the following question: "which of the following two statements about addressing global climate change comes closer to your own views, even if neither is exactly right? Rich countries, such as the U.S., Japan and Germany, should do more than developing countries because they have produced most of the world's greenhouse gas emissions so far (coded 1); or developing countries should do just as much as rich countries because they will produce most of the world's greenhouse gas emissions in the future (coded 2)." These response options were recoded with the latter response option (recoded 1) and the former (recoded 0) as dummies for logistic regression purpose. The results are shown in Table 3 below. It is obvious from Table 3 that a substantial number of respondents across all nine African countries surveyed were of the view that the rich should do more to address global climate change. On average, there is a 15 point difference between the two contrasting views (the rich-poor dichotomy) in addressing global climate change.

With respect to the effects of global climate change, respondents were presented with a list of possible effects of global climate change and asked to indicate which effect are of most concern to them. The effects covered the following: drought or water shortages; severe weather like floods or severe storms; long periods of unusually hot weather; and rising sea levels. The results in Table 3 show that drought or water shortages tops climate 
change concerns across eight countries covered, in exception to Nigeria which indicated long periods of unusually hot weather as top concern.

Table 3: Views on addressing global climate change and consequences

\begin{tabular}{|c|c|c|c|c|c|c|c|c|c|c|}
\hline \multirow[t]{2}{*}{ Variable } & \multicolumn{10}{|c|}{ Country $(\%)$} \\
\hline & 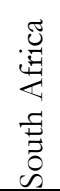 & 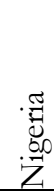 & $\frac{\Im}{\mathbb{Z}}$ & 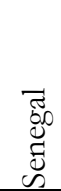 & 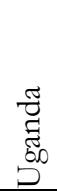 & 胥 & 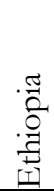 & 茎 & 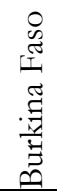 & 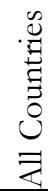 \\
\hline \multicolumn{11}{|c|}{ Views on addressing global climate change } \\
\hline $\begin{array}{l}\text { Rich countries should } \\
\text { do more }\end{array}$ & 43 & 50 & 64 & 55 & 46 & 43 & 36 & 64 & 56 & 51 \\
\hline $\begin{array}{l}\text { Developing countries } \\
\text { should do as much as } \\
\text { rich }\end{array}$ & 39 & 35 & 28 & 31 & 45 & 50 & 40 & 27 & 31 & 36 \\
\hline \multicolumn{11}{|c|}{ Effects of global climate change } \\
\hline $\begin{array}{lll}\begin{array}{l}\text { Drought } \\
\text { shortages }\end{array} & \text { or water } \\
\end{array}$ & 26 & 24 & 49 & 62 & 56 & 63 & 61 & 59 & 78 & 53 \\
\hline $\begin{array}{llr}\text { Severe } & \text { weather like } \\
\text { floods } & \text { or severe } \\
\text { storms } & & \\
\end{array}$ & 31 & 25 & 24 & 16 & 18 & 18 & 15 & 25 & 11 & 20 \\
\hline $\begin{array}{l}\text { Long periods of } \\
\text { unusually hot weather }\end{array}$ & 21 & 40 & 18 & 10 & 23 & 16 & 15 & 12 & 9 & 18 \\
\hline Rising sea levels & 8 & 4 & 6 & 8 & 3 & 1 & 3 & 2 & 1 & 4 \\
\hline
\end{tabular}




\section{Views on addressing global climate change (rich vs. poor)}

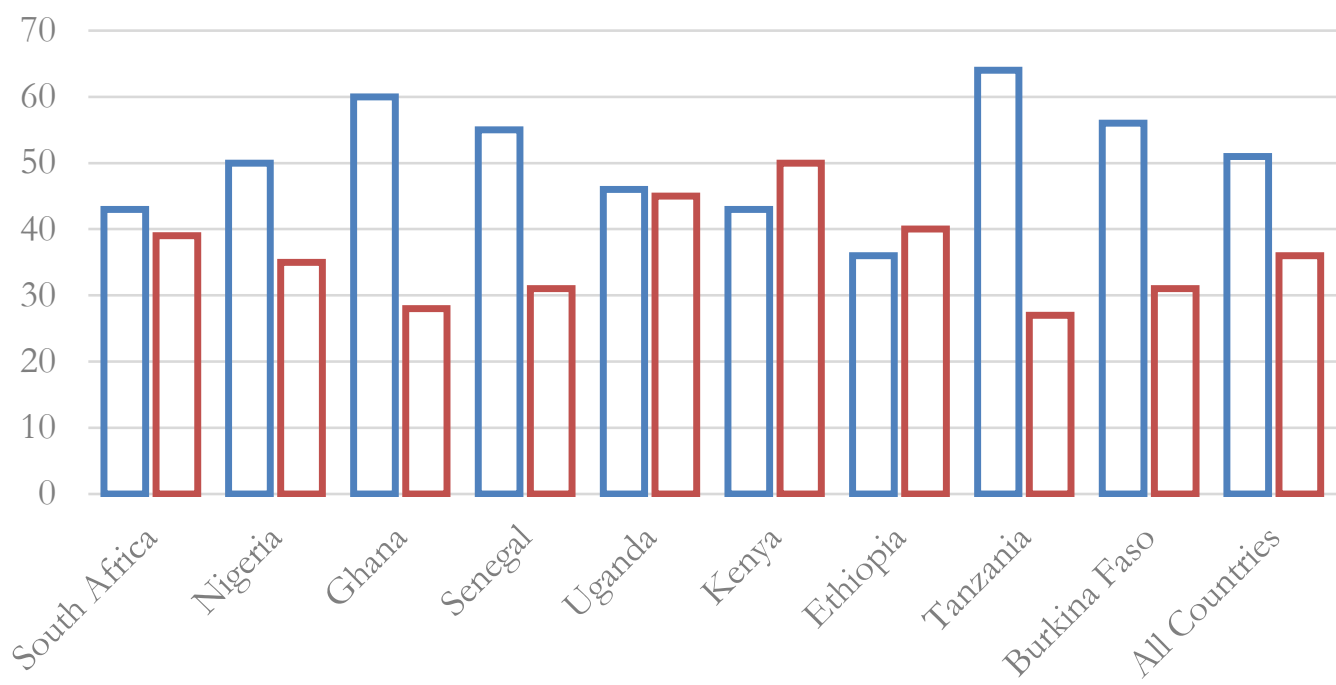

Rich countries should do more Developing countries should do as much as rich

Figure 3: Views on addressing global climate change

Political efficacy is sometimes such a nebulous concept to define and operationalize. It has internal and external dimensions, but it is usually defined from "an either or" perspective instead of both. It is the belief by a person that (s) he is capable of affecting politics (known as internal efficacy) and that the political system is responsive to him/her-known as external efficacy (Peterson (1990, p.20). When citizens feel that their views do not matter in shaping policies, they usually may not engage in political participation to influence change. Respondents were asked to indicate whether "too few citizens participating in politics" is a problem. The response options were: very big problem (coded 1), moderately big problem (coded 2), small problem (coded 3) and not a problem at all (coded 4). These were reverse coded so that greater values reflect higher levels of magnitude of the problem of too few citizen participation. The results in Table 4 show that the average is hovers around the value of 3 , meaning many are of the view that there is a problem of citizen participation.

The views of respondents were sought in relation to foreign companies in oil, petrol or mining. Specifically, they were asked to indicate how well each of the following describes foreign companies in oil, petrol, or mining industry in their respective countries: they provide jobs for local workers; they don't pay their share of taxes; they contribute to our country's economic growth. The response options were: very well (coded 1), somewhat well (coded 2), not too well (coded 3), and not well at all (coded 4). These responses were reverse coded so that higher values reflect how well the description fits respondent's views. As shown in Table 4, across all countries, then mean fluctuates around 3 for foreign companies in oil, petrol, or mining industry provide jobs for local workers, and foreign companies in oil, petrol or mining industry contribute to country's 
economic growth. This implies that the average person views fit the somewhat well category of description. The idea that foreign companies do not pay their fair share of taxes seems to be middle-of-the-road.

With respect to socio-demographics, years of schooling was measured in years. The mean is 7.7, with South Africa having the highest (10.9) years of schooling, whereas Burkina Faso has the lowest (3.9). The mean age is 35.9 years. The ratio of males to females is almost 1:1. Gender was treated as a dichotomous variable (female coded 1 and male coded zero) for multivariate analysis specifically, logistic regression purposes.

Table 4: Political participation and attitudes toward foreign companies in oil, petrol or mining and socio-demographics

\begin{tabular}{|c|c|c|c|c|c|c|c|c|c|c|}
\hline \multirow[t]{2}{*}{ Variable } & \multicolumn{10}{|c|}{ Country Mean } \\
\hline & 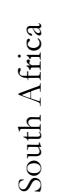 & $\begin{array}{l}. \frac{\pi}{\overrightarrow{0}} \\
\frac{.60}{Z}\end{array}$ & 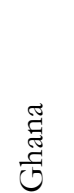 & 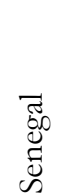 & 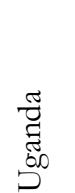 & 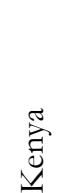 & 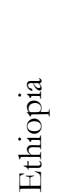 & 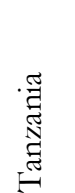 & 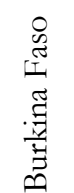 & 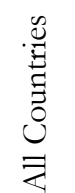 \\
\hline $\begin{array}{l}\text { Too few } \\
\text { citizens } \\
\text { participating } \\
\text { in politics } \\
\end{array}$ & 3.2 & $\frac{4}{3.3}$ & 2.9 & 2.8 & 2.9 & 2.7 & 3.0 & 3.2 & 2.7 & 3.0 \\
\hline \multicolumn{11}{|c|}{ Attitudes toward foreign companies in oil, petrol or mining } \\
\hline $\begin{array}{l}\text { Foreign } \\
\text { companies in } \\
\text { oil, petrol, or } \\
\text { mining } \\
\text { industry } \\
\text { provide jobs } \\
\text { for local } \\
\text { workers }\end{array}$ & 2.8 & 2.9 & 3.0 & 2.9 & 3.1 & 3.3 & 3.4 & 2.7 & 2.9 & 3.0 \\
\hline $\begin{array}{l}\text { Foreign } \\
\text { companies in } \\
\text { oil, petrol or } \\
\text { mining } \\
\text { industry don't } \\
\text { pay their } \\
\text { share of taxes }\end{array}$ & 2.6 & 2.8 & 2.7 & 1.9 & 2.8 & 2.6 & 2.4 & 2.4 & 2.3 & 2.5 \\
\hline $\begin{array}{l}\text { Foreign } \\
\text { companies in } \\
\text { oil, petrol or } \\
\text { mining } \\
\text { industry } \\
\text { contribute to } \\
\text { country's } \\
\text { economic } \\
\text { growth }\end{array}$ & 2.8 & 3.0 & 2.8 & 2.9 & 3.2 & 3.2 & 3.4 & 2.7 & 2.9 & 3.0 \\
\hline $\begin{array}{l}\text { Years } \\
\text { schooling }\end{array}$ & 10.9 & 10.1 & 8.9 & 5.2 & 7.6 & 9.4 & 5.3 & 8.1 & 3.9 & 7.7 \\
\hline Age & 38.7 & 34.9 & 37.3 & 36.9 & 34.1 & 35.5 & 33.8 & 36.2 & 35.9 & 35.9 \\
\hline Male & 47.6 & 50.1 & 48.4 & 51.9 & 49 & 47.9 & 49.4 & 46.8 & 52 & 49.2 \\
\hline Female & 52.4 & 49.9 & 51.6 & 48.1 & 51 & 52.1 & 50.6 & 53.2 & 48 & 50.8 \\
\hline
\end{tabular}




\subsection{Logistic Regression Model on support for or opposition to greenhouse emission}

A logistic regression analysis technique is used wherein the dependent variable is the nominal variable "whether a person supports or opposes limiting greenhouse emissions such as from burning coal or [gas/petrol]. The explanatory variables are: a series of four questions used to construct perception of severity of global climate change, responsibility in addressing climate change, perception of foreign companies in oil, petrol or mining in terms of (contributing to economic growth, providing local jobs, and not paying taxes), political participation, years of schooling, age, gender and country level dummies.

If $P$ is the probability that a person opposes limiting greenhouse emissions such as from burning coal or [gas/petrol], then the logistic regression equation is as follows:

$\ln \left[\frac{P}{1-P}\right]=\alpha_{0}+\sum_{i=1}^{n} \alpha_{i} X_{i}$

Where $\alpha_{0}$ is the intercept, $X_{i} s$ are the different explanatory variables and $\alpha_{i} S$ are the corresponding regression coefficients. Table 5 provides the values of the regression coefficients of the explanatory variables and the intercept. The table also provides the standard error (in bracket), corresponding odd ratios and levels of significance.

To find out the characteristics of individuals' support for limiting greenhouse emissions, a binary logistic regression model was performed. The results assessing the relationships between supporting limiting greenhouse emissions as the dependent variable and the corresponding independent variables - a series of four questions used to construct perception of the severity of global climate change scale, awareness of specific environmental problems, responsibility in addressing climate change, effects of global climate change, perception of foreign companies in oil, petrol or mining in terms of (contributing to economic growth, providing local jobs, and not paying taxes), political participation, years of schooling, age, gender and country level dummies are shown in Tables 5. It is a well-fitting model since it shows non-significance, where $\mathrm{p}>.05$ (Hosmer \& Lemeshow, 2000; Menard, 2002; Norusis, 2008).

Table 5: Logistic regression of support for limiting greenhouse emissions

\begin{tabular}{|l|l|l|}
\hline Independent variable & B(S.E.) & Odds Ratio \\
\hline $\begin{array}{l}\text { Perception of severity of } \\
\text { global climate change scale }\end{array}$ & $.134(.016)$ & $1.143^{* * *}$ \\
\hline $\begin{array}{l}\text { Addressing global climate } \\
\text { change (rich vrs. poor) }\end{array}$ & $.183(.066)$ & $1.201^{* *}$ \\
\hline Effects of global climate change & $1.475^{* * *}$ \\
\hline $\begin{array}{l}\text { Severe weather like floods or } \\
\text { severe storms }\end{array}$ & $.389(.080)$ & $.788^{* *}$ \\
\hline $\begin{array}{l}\text { Long periods of unusually hot } \\
\text { weather }\end{array}$ & $-.238(.088)$ & $1.651^{* *}$ \\
\hline Rising sea levels & $.501(.159)$ & $1.096^{*}$ \\
\hline Pollution and other forms of & $.091(.043)$ & \\
\hline
\end{tabular}




\begin{tabular}{|c|c|c|}
\hline environ damage & & \\
\hline Lack of clean drinking water & $.057(.045)$ & 1.059 \\
\hline \multicolumn{3}{|c|}{ Foreign companies in oil, petrol or mining industry } \\
\hline Contribute economic growth & $-.024(.041)$ & .976 \\
\hline Provide local jobs & $.003(.041)$ & 1.003 \\
\hline Don't pay taxes & $.060(.032)$ & 1.062 \\
\hline Political participation & $-.011(.035)$ & .989 \\
\hline Years of schooling & $.016(.007)$ & $1.005^{*}$ \\
\hline Age & $.005(.002)$ & $1.005^{*}$ \\
\hline Gender & $-.056(.066)$ & .945 \\
\hline South Africa & $.616(.161)$ & $1.852^{* * *}$ \\
\hline Nigeria & $.515(.149)$ & $1.674 * *$ \\
\hline Ghana & $.362(.147)$ & $1.436^{*}$ \\
\hline Uganda & $.079(.151)$ & 1.082 \\
\hline Kenya & $.552(.143)$ & $1.736^{* * *}$ \\
\hline Ethiopia & $-.112(.156)$ & .894 \\
\hline Tanzania & $.267(.146)$ & 1.306 \\
\hline Burkina Faso & $.184(.166)$ & 1.202 \\
\hline Constant & $-4.698(0.941)$ & $.009^{* * *}$ \\
\hline-2 log likelihood & 5802.2 & \\
\hline $\begin{array}{l}\text { Hosmer \& } \quad \text { Lemeshow } \\
\text { Goodness-of-Fit Test }\end{array}$ & .623 & \\
\hline $\mathrm{N}$ & 9062 & \\
\hline
\end{tabular}

Significance for coefficients: ${ }^{*} p<.05 ;{ }^{* *} p<.01 ; * * p<.001$

\section{Analysis}

It is obvious from findings on the surveyed African countries that there is a high perception of the severity of global climate change. Relatedly, there was also high level of awareness in relation to pollution and other forms of environmental damage; and lack of clean drinking water. Across the globe, the poor have historically borne much of the brunt of environmental inequalities, suffering disproportionately from exposure to environmental hazards and the effects of pollution. Thus, environmental concern is not the preserve of only developed countries.

In fact, citizens of the Global South also have a "fair share" of environmental concern due to the fact that they can see the realities of environmental crisis which threaten current and future generations. Being poor and having materialist value-orientations does not deprive people in the Global South from pro-environmental attitudes. It can further be argued that the ecological paradigm and post-materialist perspectives provide insight into rational behaviors of citizens in both the Global South and North. Irrespective of geographical location, having post-materialist or materialist value-orientation, desired environmental outcomes may be achieved by adopting the ecological modernization policy prescriptions.

People's perception of the severity of climate change positively impacts on their support to limiting greenhouse emissions. In Africa, those who hold the view that developing countries should do as much as the rich countries because they (developing countries) 
will produce most of the world's greenhouse emissions in future are more likely to support limiting greenhouse emissions. As a result of industrialization in both developed and developing countries, large amounts of fossil fuels and natural resources are consumed. This creates myriad environmental problems. Adopting a more ecologically sustainable form of economic development may address the environmental problems while at the same time enhancing the wellbeing of society. It appears that even though African countries are relatively poor compared with developed nations, citizens recognize the need to take responsibility to avert devastating environmental crisis. For African countries, economic development goals can be pursued with ecological considerations coupled with building social institutions to avert ecological crisis. It is worthy of note that there was a prevalent view that foreign companies in oil, petrol or mining industry contribute to countries' economic growth and provide local jobs.

The logistic regression models reveal that people's rational insight into the following consequences of climate change positively predicts support for limiting greenhouse emissions: severe weather like floods or severe storms; long periods of unusually hot weather; rising sea levels; years of schooling and age. In general, knowing an individual's country of residence in no way provides any predictive value in determining whether the individual could support limiting greenhouse emissions. The notable exceptions are: South Africa, Nigeria, Ghana and Kenya. These four countries display positive and statistically significant coefficients in the logistic regression model predicting support for greenhouse emissions.

\section{Conclusion}

The findings offer further insight into how the publics' knowledge of and rational insight into climate change and its associated risks are substantively linked to their (public's) support for limiting greenhouse emissions and policy options to address it. It is apparent that people of the surveyed African countries perceive that in order to mitigate adverse climate change, they need to take action to reduce greenhouse emissions. There is a pervasive awareness or perception of the severity of specific environmental problems that endanger the natural environment coupled with a willing attitude to take action to protect it for the sake of the well-being of current and future generations.

\section{References}

Brechin, S. \& Kempton, W. (1997). Beyond Postmaterialist Values: National versus Individual Explanations of Global Environmentalism. Social Science Quarterly. Vol. 78, No. 1, pp. 16-20.

Buttel, Fred H., 2009. Ecological modernization as social theory. In: Mol, A.P.J., Sonnenfeld, D.A., Spaargaren, G. (Eds.). The Ecological Modernization Reader: Environmental Reform in Theory and Practice. Routledge, London and New York, pp. 123-137.

Catton, William \& Dunlap, Riley (1980). A New Ecological Paradigm for PostExuberant Sociology. American Behavioral Scientist. 24:15-37.

Dietz, Thomas, Amy Dan \& Rahael Shwom. (2007). Support for Climate Change Policy: Social Psychological and Structural Influences. Rural Sociology. 72(2). Pp. 185214. 
Dunlap, R. \& Jones, R. (2002). Environmental concern: conceptual and measurement issues. In: Dunlap, R.E., Michelson, W. (Eds.). Handbook. Environmental Sociology. Greenwood Press, Westport, pp. $482-$ 524.

Dunlap, Riley (1980). "Paradigmatic Change In Social Science. From Human Exemptionalism to an Ecological Paradigm." American Behavioral Scientist. 24:5-14.

Dunlap, R. \& Mertig, A. (1997). Global Environmental Concern: An Anomaly for Postmaterialsim. Social Science Quarterly. Vol. 78, No. 1, pp 24-29.

Dunlap, R. E. \& Catton, Jr., W. R. (1994). Toward an ecological sociology. In W. V. D' Antonio, M. Sasaki, \& Y. Yonebayashi (Eds.), Ecology, society and the quality of social life. Pp. 11-31. New Brunswick. NJ Transaction.

Frazen, A. \& Meryer, R. (2010). Environmental attitudes in cross-national perspectives: a multilevel analysis of the ISSP 1993 and 2000. European Sociological Review, 26, pp.219-234.

Guha, R. (1989). The Unquiet Woods. Oxford University Press, Delhi.

Hosmer, D. W., \& Lemeshow, S. (2000). Applied logistic regression. New York: John Wiley and Sons.

Huber, J. (2009a). Ecological modernization: beyond scarcity and bureaucracy. In: Mol, A.P.J., Sonnenfeld, D.A., Spaargaren, G. (Eds.). The Ecological Modernization Reader: Environmental Reform in Theory and Practice. Routledge, London and New York, pp. 42-55.

IPCC. (2007). Climate Change 2007: Synthesis Report. In: An Assessment of the Intergovernmental Panel on Climate Change.

IPCC (2018). Summary for Policymakers. In: Global Warming of $1.5^{\circ} \mathrm{C}$. An IPCC Special Report on the impacts of global warming of $1.5^{\circ} \mathrm{C}$ above pre-industrial levels and related global greenhouse gas emission pathways, in the context of strengthening the global response to the threat of climate change, sustainable development, and efforts to eradicate poverty [Masson-Delmotte, V., P. Zhai, H.-O. Pörtner, D. Roberts, J. Skea, P.R. Shukla, A. Pirani, W. Moufouma-Okia, C. Péan, R. Pidcock, S. Connors, J.B.R. Matthews, Y. Chen, X. Zhou, M.I. Gomis, E. Lonnoy, T. Maycock, M. Tignor, and T. Waterfield (eds.)]. In Press.

IPCC, 2014. Climate Change Synthesis Report (Longer Report). IPCC Fifth Assessment Synthesis Report.

Jensen, J. \& Gram-Hanssen, K. (2008). Ecological modernization of sustainable buildings: a Danish perspective. Build. Res. Inf. 36 (2), 146-158.

Marquart-Pyatt, S. (2012). Contextual influences on environmental concerns cross-nationally: a multilevel investigation. Soc. Sci. Res. 41, pp. 1085-1099.

Menard, S. (2002). Applied logistic regression analysis. Thousand Oaks, London: Sage Publications.

Mol, A. (2002). "Ecological Modernization and the Global Economy." Global Environmental Politics. 2(2): 92115.

Mol, A. \& Janicke, M. (2009). The origins and theoretical foundations of the ecological modernization theory. In: Mol, A.P.J., Sonnenfeld, D.A., Spaargaren, G. (Eds.). The Ecological Modernization Reader: Environmental Reform in Theory and Practice. Routledge, London and New York, pp.17-27.

Murphy, J. Gouldson, \& A. (2009). Environmental policy and industrial innovation: integrating environment and economy through ecological modernization. In: Mol, A.P.J., Sonnenfeld, D.A., Spaargaren, G. (Eds.). The Ecological Modernization Reader: Environmental Reform in Theory and Practice. Routledge, London and New York, pp. 257-294.

Norusis, M. (2008). SPSS 16.0 Statistical procedures companion. Prentice Hall Inc.

Peterson, S. A. (1990). Political behavior: Patterns in every day life. Newbury Park, CA: Sage.

Pew Research Center, July, (2015). "Climate Change Seen as Top Global Threat."

Spaargaren, G, \& Mol, A. (2009). Sociology, environment, and modernity: ecological modernization as a theory of social change. In: Mol, A.P.J., Sonnenfeld, D.A., Spaargaren, G. (Eds.). The Ecological Modernization Reader: Environmental Reform in Theory and Practice. Routledge, London and New York, pp. 56-79. 